International Journal of Current Advanced Research

ISSN: O: 2319-6475, ISSN: P: 2319 - 6505, Impact Factor: SJIF: 5.995

Available Online at www.journalijcar.org

Volume 6; Issue 3; March 2017; Page No. 2616-2618

DOI: http://dx.doi.org/10.24327/ijcar.2017.2618.0058

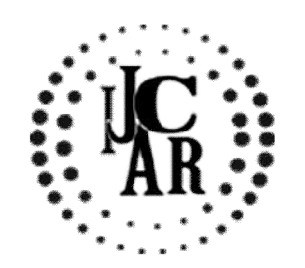

Research Article

\title{
FORMULATION OF INDIGEOUS PROTOCOL FOR THE MANAGEMENT OF MUSCULAR DISTROPHIES
}

\author{
Rana A P1 ${ }^{1,}$ Nikam A $S^{2}$., Shrivas $Y^{2}$ and Swami T Y1 \\ ${ }^{1}$ Balrog Department GAC \& H osmanabad \\ 2Balrog Department GAC\&H Nagpur
}

\section{A R T I C L E I N F O}

\section{Article History:}

Received $18^{\text {th }}$ December, 2016

Received in revised form $16^{\text {th }}$ January, 2017

Accepted $26^{\text {th }}$ February, 2017

Published online $28^{\text {th }}$ March, 2017

\begin{abstract}
A B S T R A C T
Duchenne muscular dystrophy (DMD) is an X- linked recessive disorder in which lack of protein produced by gene Dystrophin leads to the progressive muscle wasting. The incidence of disease is 1: 3500 to 4000 male children[1]. According to Ayurveda it has been classified under aadibala parvritta vyadhi and it occurs due to Bheejabhagaavyava vikruti leading to medo mamsavaha dushti resulting in DMD like presentation. At present no satisfactory treatment have been developed to date. The drug Eteplirsen by Sarepta pharmaceutical uses phosphorodiamidate morpholino oligomer (PMO)-based chemistry and proprietary exon-skipping technology has been developed to skip mutations affecting exon 51 of the dystrophin gene[2]. But this treatment cost is nearly 2 crores yearly. As Ayurvedic regimen DMD formula in form of churna shows great improvement and is cost effective too. Also panchakarma therapy in the form of Abhyanga, Shashtishalik, Pindasweda, Basti has been taken along with Ayurvedic regime. This pioneer approach can render the patient quality of life and longer survival upon muscular dystrophy. Hence this treatment results has been proposed for submission..in this case series all five patient have shown decrease in total cpk level after 1 month of therapy. with paired t-test SD = $9957, \mathrm{SE}=4445, \mathrm{df}=4, \mathrm{n}=5$ study results are significant at $5 \%$ level of significance with confidence interval of $95 \%$ as $t_{4}=3.43$.clinical improvement of symptom was observed in terms of decreased rigidity of calf muscles.there ability to walk climb or doing daily routine improved to some extent.
\end{abstract}

Copyright $₫ 2017$ Rana A P et al. This is an open access article distributed under the Creative Commons Attribution License, which permits unrestricted use, distribution, and reproduction in any medium, provided the original work is properly cited.

\section{INTRODUCTION}

According to World Health Organization (WHO- 2013) An $\mathrm{X}$ - linked neuromuscular disease characterise by rapidly progressing muscle weakness \& wasting. Incidence - 1: 3500 to 4000 male children. In this $1 / 3$ of these with previous family history \& $2 / 3$ sporadic. $1^{\text {st }}$ symptoms noticed on average at 3.6 yrs."Duchenne muscular dystrophy (DMD) is a hereditary neuromuscular disorder characterised by muscular weakness, calf hypertrophy, proliferation of connective tissue within the muscles \& mental retardation."Genotypically confirmed Duchenne muscular dystrophy (DMD) with genetic deletions amenable to correction by exon 51 skipping, eteplirsen may restore the gene's ability to make a shorter. But treatment cost is nearly 2 crores yearly. As far as management or preventive aspect is concerned, no satisfactory criteria have been developed to date. The use of PANCHAKARMA Procedures \& specific oral AYURVEDIC HERBAL MEDICATIONS have been found to improve the quality of living of children with DMD.

*Corresponding author: Rana A P, Balrog Department GAC \& H osmanabad
Aims

To design the IISM protocol for management of DMD with AYUSH Management therapy.

Objective

1. To evaluate effect of AYURVEDIC REGIMEN in DMD.

2. To treat patients of DMD along with DMD Formulations.

3. Regimen was prepared according to GMP guidelines $\&$ their safety was Assured as herbal drugs were used for preparation of regimen to used.

4. To have better understanding of disease and ayurvedic therapeutics, Biochemical, Biophysical and Histopathological genetic parameters of disease diagnosis.

\section{MATERIALS AND METHODS}

\section{Place of Study}

Patient were screened in balrog opd and enrolled according to diagnostic \& inclusive criteria. 


\section{Consent}

A well informed consent was taken from all patient/ guardians before start of study.

\section{Types of Study}

The present study is single group study, prospective clinical trial in children with DMD

\section{Diagnostic Criteria}

Patients presenting with the clinical picture of proximal muscle weakness, difficulty while standing, climbing staircase, pseudo-hypertrophy of calf muscles, positive Gower's sign, 6 min walking test with confirmative test as serum CPK values, testing for DMD mutation in blood sample (Genetic test - multiplex PCR), EMG - NCV Test, Histopathological report.

\section{Sample Size}

The sample size of 5 patients given the following regimen for treatment.

\section{Regimen Included In Study}

1. Panchakarma Chikitsa

2. Rasayan Aushadhi in the form of DMD formula

3. Treatment of associated symptoms.

Panchakarma chikitsa includes - Sarvang Abhyanga, Pindsweda, Basti.

Abhyanga - til tailum.

Shalishastik Pind sweda

Basti- karmabasti krama - DMD FORMULA siddha tailum for Matrabasti \& Anuvasan basti.

Niruha basti - decoction of DMD formula.

DMD Formula - contains 8 drugs i.e

Guduchi (Tinosporia Cordifolia)
Musta (Cyperus Rotundus)
kiratatiktta (Swertia Chirayta)
Punarnava (Boerhavia diffusa)
Chandan (Santalum album)
Gokshur(Tribullus terestris)
Sariva(Hemidesmus Indicus)
Patola (Trichosanthes diocia)

8 Drugs- $1 \mathrm{gms}$ to $10 \mathrm{gms}$ tds(125mg each) in Churna form.as per age according to young or clarks formula for dose calculation

\section{Anupana Dravya}

Leuke warm water as per need

\section{Basti Treatment}

As per convention Sarvang abhyanga with til tailum \& Sarvanga Pinda Swedan was given to the patient for 6 months. basti was given for 30 days as per Karma Basti Krama with a interval of one month after each cycle. basti was given after Sarvang abhyanga with til tailum \& Sarvanga Pinda Swedan as per text. Total 3 cycles of basti was given throughout the treatment.

\section{METHODOLOGY}

Matra Basti (M):- DMD formula siddha tail. $(5 \mathrm{ml}$ to $60 \mathrm{ml})$
Anuwasan Basti (A):- DMD formula siddha tail.(10 $\mathrm{ml}$ to 120 $\mathrm{ml})$

Niruha Basti (N):- Decoction of DMD Formula.(80 ml to 960 ml)as per age according to charak samhita bastisiddhir chapter no 3 in siddhi sthana.basti prepared as per recommended method niruha basti preparation

Karma Basti Krama used was

MMM+ N1A1 N2A2 N3A3 N4A4 N5 A5 N6A6 N7A7 N8A8 N9A9 N10A10 + MMM End of Cycle.

Such 3 cycles of Basti was given as karmabasti karma schedule mention above of 30 days, with a interval of one month after each cycle.basti was prepared and given as per the reference of Charak Samhita. Where as DMD formula churna was continued throughout the duration of treatment.

Improvement in physical ability in terms of daily routine activities in term of walking, sitting, posture, stance, gait etc was observed. No scale for assessment was derived as sample was small and study was of small duration.no previous supported study were there to note improvement but after this study need of deriving scales for assessment of such patients is there for large multicentric trials.

\section{Duration of Study}

Duration of study was 6 months.

\section{Inclusion Criteria}

Male 1-16 years old

Diagnosed with DMD, genotypically confirmed.

Have intact right and left alternative upper muscle groups

Mean 6MWT greater than $300 \mathrm{~m}$ (primary analysis on 300 to 450 meters)

Physically stable

\section{Exclusion Criteria}

Previous treatment with drisapersen within the last 6 months Participation in any other DMD interventional clinical study within 12 weeks

Major surgery within 3 months

Presence of other clinically significant illness

Major change in the physical therapy regime within 3 months

\section{OBSERVATIONS AND RESULTS}

All the observed data was subjected to statistical analysis and was analysed.it shows that the total cpk level were decreased after 1 month of treatment. With paired t-test $\mathrm{SD}=9957, \mathrm{SE}=$ $4445, \mathrm{df}=4, \mathrm{n}=5$ study results are significant at $5 \%$ level of significance with confidence interval of $95 \%$ as $t_{4}=3.43$. Clinical improvement of symptom was observed in terms of decreased rigidity of calf muscles. There ability to walk climb or doing daily routine improved to some extent. There extension of shoulder and arms improved as they started using it for picking objects better than before $=$. Some patients were not able to eat with their hands started using spoons for eating with little assistance for care takers. Some patients mobility have improved as they were not ambulant before starting a treatment. Now they are able to sit with support on wheel chair as they can hold their body in a plane to some extent. Some patients neck movement also increased as a result of that their visual field has increased. Now they are more attached to the surrounding. Patient's social invovlement has 
increased as a result of that they started interacting with their peers. They started playing simple games like picking the balls, rings, etc as a part of their occupational therapy. During physiotherapy it has been observed that the angles of extension of their joints like shoulder joint, elbow joint, wrist joint, hip joint, knee joint, ankle joint. So it has been observed that this regimen is helpful to serve DMD patients.

\section{DISCUSSION}

The observation and results shows that the total cpk level were decreased after 1 month of treatment .clinical improvement of symptom was observed in terms of decreased rigidity of calf muscles.there ability to walk climb or doing daily routine improved to some extent.this suggests that there might be some biochemical changes occurred due to which cpk level decreased. This observation have ray of hope that this regimen have some role to play with muscle destruction pathology. Futher molecular study is needed to understand this. This regimen should be used in other musculoskeletal disorders. Longitivity and quality of life might improve in such patients on long term use as it is safe combination.

\section{Summary}

Patient were screened in balrog opd and enrolled according to diagnostic \& inclusive criteria. Sarvanga abhyanga with tiltailum \& Sarvanga Pind Swedan was given to the patient for 6 months along with DMD formula churna. As per convention before basti, Sarvanga abhyanga with tiltailum \& Sarvanga Pind Swedan was given to the patient each time. The basti was given as per Karma Basti Krama.Such 3 cycles of Basti was given with the interval of 1 month. DMD formulation was given for 6 months. Abhyanga, Pindsweda was continued daily for 6 month.the observation shows that the total cpk level were started decreasing after 1 month of treatment only. Clinical improvement of symptom was observed in terms of decreased rigidity of calf muscles.there ability to walk climb or doing daily routine improved to some extent.

\section{CONCLUSION}

This regimen should be proposed for larger trial involving multicenters for study.we can come up with better understanding of muscular dystrophies.may be any concrete treatment of this disorder might come out of it.large sample need to be derived for futher study.

\begin{tabular}{ccc}
\hline sample & $\begin{array}{c}\text { Before CPK LEVELS (CPK } \\
\text { TOTAL) } \mathbf{~ m U / m l}\end{array}$ & After \\
\hline Patient 1 & 28950 & 9340 \\
Patient 2 & 8420 & 120 \\
Patient 3 & 9760.8 & 28.9 \\
Patient 4 & 9826 & 2041 \\
Patient 5 & 34700 & 3850 \\
\hline
\end{tabular}

\section{Reference}

1. Current Status of Pharmaceutical and Genetic Therapeutic Approaches to Treat DMD in Molecular Therapy 19(5):830-40 - April 2011 with 112 Reads DOI: $10.1038 / \mathrm{mt} .2011 .59 \cdot$ Source: PubMed

2. Confirmatory Study of Eteplirsen in DMD Patients (PROMOVI). Verified December 2014 by Sarepta Therapeutics

3. Charak I.T., $1994-12^{\text {th }}$ Edition ,Hindi commentary by PL. Kashinath Shastri and Dr. G.N. Chaturvewdi Chaukhabha Barati Academy, Banaras.

4. Sushrut,1997, $11^{\text {th }}$ Edition -Ambikadatta Shastri, Sanskrit Sanstan.

5. Ashtang Hriday-Atrideo Gupta.

6. Sushtrut Samhita, Jyotir Mitra Acharya

7. Ashtang Sangrah, - Shrikant Murthi, English Edition.

8. Chakradatta- Sanskrit Teeka.

9. Bhavprakash Samhita- I, II - Chaukhabha Bharti Academy, Banaras.

10. Dravya Guna Vidnan I, II $-1993,14^{\text {th }}$ Edition by prof. P.V. Sharma, Chaukhabha Bharati Academy, Varanasi.

11. Rudolph Textbook of pediatrics

\section{Please cite this article in press as:}

Rana A P et al (2017), 'Formulation Of Indigeous Protocol For The Management Of muscular distrophies', International Journal of Current Advanced Research, 6(3), pp. 2616-2618.

http://dx.doi.org/10.24327/ijcar.2017. 2618.0058 